\title{
Efficient photocatalytic degradation of NO by ceramic foam air filters coated with mesoporous $\mathrm{TiO}_{2}$ thin films
}

\author{
Wingkei Ho ${ }^{\mathrm{a}, \mathrm{b}, *}$ \\ a Department of Science and Environmental Studies and Center for Education in Environmental Sustainability, The Hong Kong Institute of Education, \\ Tai Po, N.T. Hong Kong, China \\ ${ }^{\mathrm{b}}$ Department of Civil and Environmental Engineering, Research Center for Environmental Technology and Management, The Hong Kong Polytechnic \\ University, Hong Kong, China
}

\section{A R T I C L E I N F O}

\section{Article history:}

Received 31 August 2015

Accepted 29 October 2015

Published 20 December 2015

\section{Keywords:}

Titania

Photocatalysis

Ceramic

Nitrogen oxide

Coating

\begin{abstract}
A B S T R A C T
Ceramic foam air filters with three-dimensional (3D) porous structures and high surface areas were coated with mesoporous $\mathrm{TiO}_{2}$ thin films by the reverse micellar method. The mesoporous $\mathrm{TiO}_{2}$ thin films efficiently photocatalytically degraded nitrogen oxide (NO). More than $92.5 \%$ of NO was degraded in a single pass for air filter samples containing different pore densities. The 3D porous structure of the ceramic air filters enhanced flow turbulence and mixing. This provided the catalytic system with excellent gas-dynamic properties, and sufficient contact between the reactant gas and catalyst surface. The higher pore density of the ceramic foam filters resulted in a higher photocatalytic rate. More adsorption sites for water vapor and the reactant and product gases improved the photocatalytic activity. The porous ceramic air filters coated with mesoporous $\mathrm{TiO}_{2}$ had large surface areas, and thus high photocatalytic activity. This overcame the common disadvantages associated with using powdered $\mathrm{TiO}_{2}$ photocatalysts on substrates. The 3D porous ceramic foam filters coated with mesoporous $\mathrm{TiO}_{2}$ thin films exhibited a higher photocatalytic degradation rate of $\mathrm{NO}$ in air than the same thin film deposited on flat ceramic tiles. No deactivation was observed. A consistently high NO degradation rate was obtained between reaction cycles for the $\mathrm{TiO}_{2}$-coated $3 \mathrm{D}$ porous ceramic filters.
\end{abstract}

(C) 2015, Dalian Institute of Chemical Physics, Chinese Academy of Sciences. Published by Elsevier B.V. All rights reserved.

\section{Introduction}

Indoor air quality has been of increasing concern in recent years, as it directly affects health because of prolonged indoor inhabitation [1-3]. People generally spend more than $80 \%$ of time inside [4], where common pollutants including $\mathrm{CO}$, nitrogen oxides $\left(\mathrm{NO}_{x}\right)$, and volatile organic compounds (VOCs) can adversely affect health [5]. Modern buildings are designed to be more airtight, to decrease energy consumption. Decreasing the intake of fresh air causes an undesirable build-up of these indoor air pollutants. Domestic appliances such as stoves and heaters are common sources of pollutants, particularly those burning coal, oil and natural gas in poorly ventilated areas [6]. Conventional remediation techniques include adsorption and filtration, which are expensive and inappropriate for low-concentration pollutants [7]. Filters without an adequate

\footnotetext{
* Corresponding author. Tel: +852-29488255; E-mail: keithho@ied.edu.hk This work was supported by the Research Grant of the Early Career Scheme (ECS 809813) from the Research Grant Council, Hong Kong SAR Government, the Dean's Research Fund-Early Career Researchers (04022), the Research Equipment Grant (REG-2), the Internal Research Grant (R3429) from the Hong Kong Institute of Education, the grants from the Research Grants Council of the Hong Kong Special Administrative Region, China (PolyU 5204/07E) and the Hong Kong Polytechnic University (GYX75).
} DOI: 10.1016/S1872-2067(15)61003-8 | http://www.sciencedirect.com/science/journal/18722067 | Chin. J. Catal., Vol. 36, No. 12, December 2015 
replacement can also be a source of VOCs in ventilation systems [8]. A different approach is required to reduce pollutant levels and maintain clean environments for good health.

Photocatalysis is a promising solution for removing indoor air pollutants. $\mathrm{TiO}_{2}$ [9-16], bismuth titanate and strontium titanate [17-19] are attractive photocatalysts because of their strong oxidizing power, non-toxicity, and long-term photostability. $\mathrm{TiO}_{2}$ photocatalysts are widely reported, usually in the form of highly dispersed or suspended fine particles/powders in liquid media. However, powdered $\mathrm{TiO}_{2}$ photocatalysts are unsuitable for air purification, because particles may become respirable and cause health problems. Various studies have immobilized $\mathrm{TiO}_{2}$ particles as thin films on rigid supports, such as glass, stainless steel, and aluminum plates [20-32].

Coating a substrate affects its surface adsorption of reactants for photocatalysis. Photocatalytic thin films are usually coated on flat surfaces, such as honeycomb air filters. In the current study, we used three-dimensional (3D) porous ceramic foam as the coating substrate, because of its excellent hydrodynamic properties for gas passing. The ceramic foam has a versatile pore density, surface area, and chemistry. The 3D porous ceramic foam air filters have a high bed porosity, which results in the low-pressure drop required by such filters. Unlike honeycomb air filters, the 3D porous ceramic foam filters have convoluted pore structures that promote turbulence and mixing. Their open porous and reticulate structure provides favorable gas-dynamic properties, and sufficient contact between the reactant gas and catalyst surface. Porous materials are advantageous in liquid or gas phase catalysis [33-35]. Thus, highly porous materials such as ceramic foam [36-38], porous alumina [39,40], porous silica [41], zeolite [42], and activated carbon [43] are common catalyst supports.

Depending on the method, depositing $\mathrm{TiO}_{2}$ films on solid substrates may reduce the effective surface area of the $\mathrm{TiO}_{2}$ photocatalyst, and thus decrease photocatalytic activity. $\mathrm{TiO}_{2}$ thin films with a mesoporous structure exhibit high photocatalytic activity, because the structure has a high specific surface area with abundant active sites [44-47]. Mesoporous $\mathrm{TiO}_{2}$ coatings on flat glass, stainless steel, and aluminum substrates have exhibited enhanced photocatalytic efficiency in environmental purification applications $[16,44,48,49]$. In the current study, we coated high surface area 3D porous foam filters with uniform mesoporous anatase $\mathrm{TiO}_{2}$ thin films. The mesoporous $\mathrm{TiO}_{2}$ coatings had a large surface area and exhibited high photocatalytic activity, and overcame the disadvantages associated with powdered $\mathrm{TiO}_{2}$ photocatalysts. This is the first reported photocatalytic degradation of $\mathrm{NO}$ by mesoporous $\mathrm{TiO}_{2}$ thin films coated on 3D porous ceramic foam air filters prepared via the reverse micellar method. NO was used as the target air pollutant because it is a major indoor air pollutant with adverse health effects. Levels of $\mathrm{NO}$ and $\mathrm{NO}_{2}$ in indoor environments are normally several hundred ppb and less than a hundred ppb, respectively [50-52].

\section{Experimental}

All chemicals were of reagent grade and were purchased from Aldrich, USA.

\subsection{Preparation of $\mathrm{TiO}_{2}$ thin films}

Triton X-100 and water were added to cyclohexane to obtain $0.2 \mathrm{~mol} / \mathrm{L}$ Triton $\mathrm{X}-100$, at a 1.5 molar ratio of water to surfactant. After stirring for $2 \mathrm{~h}$ to form a microemulsion, the reverse micellar solution was mixed with titanium isopropoxide $(0.4 \mathrm{~mol} / \mathrm{L})$. The alkoxide solution was stirred at room temperature for $1 \mathrm{~h}$ to hydrolyze and condense the titanium alkoxide. $\mathrm{A} \mathrm{TiO}_{2}$ sol was formed within the water droplets. The porous ceramic foam filters were then dip-coated in the $\mathrm{TiO}_{2}$ reverse micellar solution at ambient atmosphere. The withdrawal speed was controlled at $4 \mathrm{~mm} / \mathrm{s}$. The $\mathrm{TiO}_{2}$ gel films on the porous ceramic foam filters were calcined in air at a heating rate of $3{ }^{\circ} \mathrm{C} / \mathrm{min}$ to $500{ }^{\circ} \mathrm{C}$, and were then placed in a furnace at the highest temperature for different times. After calcination, transparent $\mathrm{TiO}_{2}$ films on the porous ceramic foam filters were obtained (Fig. 1). Porous ceramic foam filters containing pore densities of 10, 20, and 30 pores per inch (ppi) were used for comparison.

\subsection{Characterization}

X-ray diffraction (XRD) patterns were obtained using a Bruker D8 Advance X-ray diffractometer with $\mathrm{Cu}-K_{\alpha}$ radiation $(\lambda=1.54178 \AA)$ at a scan rate of $0.05^{\circ} / \mathrm{s}$, and were used to identify the phase compositions and crystallite sizes of samples. An accelerating voltage of $40 \mathrm{kV}$ and an applied current of $40 \mathrm{~mA}$ were used. X-ray photoelectron spectroscopy (XPS) was performed using a PHI Quantum 2000 XPS System, with a monochromatic $\mathrm{Al}-K_{\alpha}$ source and charge neutralizer. All binding energies were referenced to the $\mathrm{C} 1 s$ peak of adventitious carbon at $284.8 \mathrm{eV}$. Ultraviolet-visible (UV-Vis) diffuse reflectance spectra were obtained using a UV-Vis spectrophotometer (Cary 100 Scan Spectrophotometers, Varian, USA). The morphology and chemical composition of the thin films were examined using a scanning electron microscope (SEM, LEO 1450VP) at-

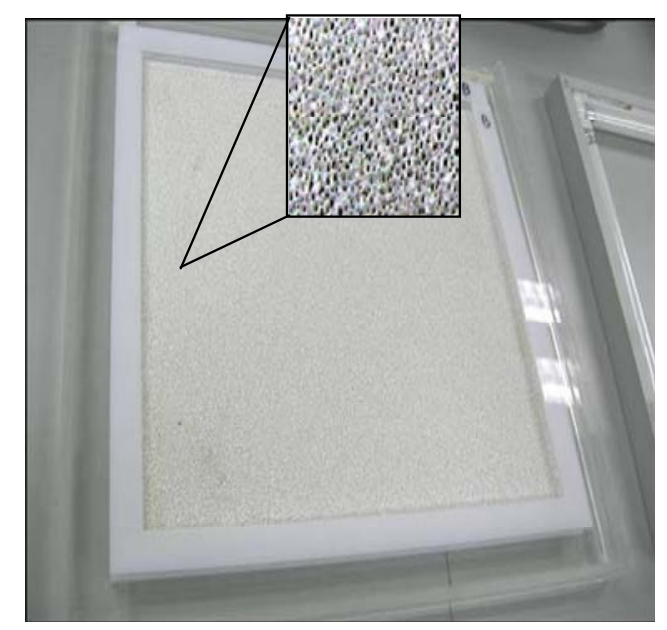

Fig. 1. Images of the photocatalytic porous ceramic air filter. Inset: Higher magnification of the ceramic foam air filter showing the porous structure. 
tached to an energy-dispersive X-ray spectrometer (EDXS, Oxford Instrument). Samples were coated with Au before SEM imaging, using a sputtering thin film coating system. Brunauer-Emmett-Teller (BET) surface areas $\left(S_{\mathrm{BET}}\right)$ and pore parameters of the powder samples were determined by $\mathrm{N}_{2}$ adsorption-desorption isotherm measurements at $-196{ }^{\circ} \mathrm{C}$, using a nitrogen adsorption apparatus (Micromeritics ASAP 2010). All samples were degassed at $180{ }^{\circ} \mathrm{C}$ prior to measurement. Pore size distributions were calculated from desorption branches of the isotherms by the Barrett-Joyner-Halenda (BJH) method using the Halsey equation. The surface roughness of the $\mathrm{TiO}_{2}$ thin films was evaluated by atomic force microscopy (AFM, NanoScope 3a, Digital Instruments Inc., Santa Barbara, CA, USA).

\subsection{Photocatalytic activity measurement}

The photocatalytic activities of the samples for the oxidation of NO in air were performed at ambient temperature in a continuous flow reactor (Fig. 2). The rectangular reactor was made of stainless steel and covered with Saint-Glass, and had a volume of $27.3 \mathrm{~L}(13 \times 70 \times 30 \mathrm{~cm})$. Illumination was provided by three 14-W commercial UVA light tubes, which emit a primary wavelength at $365 \mathrm{~nm}$, and the intensity was determined using a UV meter (Spectroline DRC-100X). The UV light tubes were horizontally placed outside the reactor above the sample. The $\mathrm{TiO}_{2}$-coated porous ceramic foam filters $(30 \times 30 \times 1 \mathrm{~cm})$ were fixed within a polytetrafluoroethylene film-coated stand, and placed horizontally $5 \mathrm{~cm}$ below the UV lamp. The total UV intensity at $310-400 \mathrm{~nm}$ incident on the filters was $540 \pm 10$ $\mu \mathrm{W} / \mathrm{cm}^{2}$, and the UV peak wavelength was $365 \mathrm{~nm}$, as determined using a UV radiometer (UVX, UVP, Inc., CA, USA). The initial concentration of water vapor was $1.20 \pm 0.02 \mathrm{vol} \%$, and the initial temperature was $25 \pm 1{ }^{\circ} \mathrm{C}$. Stainless steel sampling ports and polytetrafluoroethylene tubing were used to connect the reactor and analytical instruments.

NO gas was used as the target pollutant for the photocatalytic degradation at ambient temperature. A compressed gas cylinder provided 48 ppm NO ( $\mathrm{N}_{2}$ balance, BOC gas) with a traceable standard, from the National Institute of Stands and

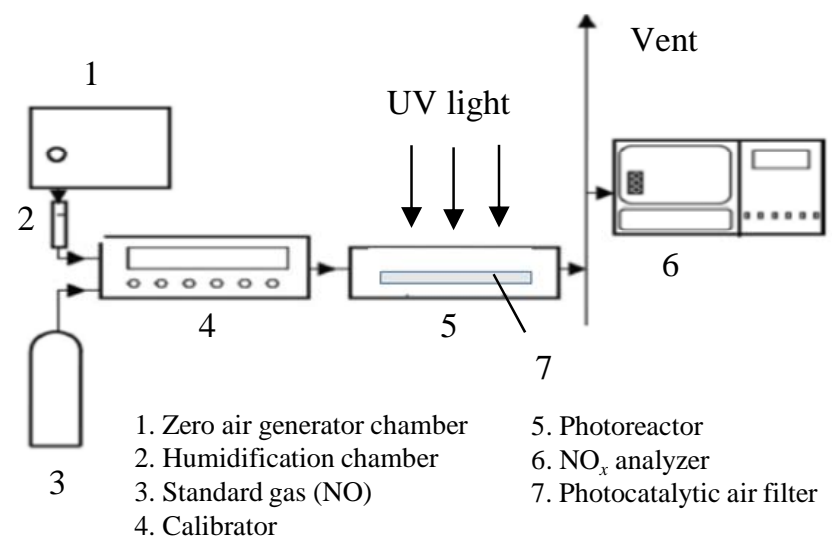

Fig. 2. Schematic design of the experimental setup for $\mathrm{NO}_{x}$ removal test by using one photocatalytic ceramic foam air filter $(30 \times 30 \times 1 \mathrm{~cm})$.
Technology (NIST). The NO initial concentration was diluted to 1000 or $400 \mathrm{ppb}$ with an air stream supplied using a zero-air generator (Thermo Environmental Inc. Model 111). The required humidity level of the NO flow was controlled at $70 \%$ (2100 ppm) by passing the zero-air stream through a humidification chamber. The gas streams were completely pre-mixed using a gas blender, and the flow rate was controlled at $4 \mathrm{~L} / \mathrm{min}$ with a mass flow controller. After the inlet and outlet concentrations of the target pollutants achieved adsorption-desorption equilibrium, the UV lamp was switched on and the reaction was initiated. The NO concentration was continuously measured using a chemiluminescence NO analyzer (Thermo Environmental Instruments Inc. Model 42c), which monitored $\mathrm{NO}, \mathrm{NO}_{2}$, and $\mathrm{NO}_{x}$ (where $\mathrm{NO}_{x}$ represents $\mathrm{NO}+\mathrm{NO}_{2}$ ) with a sampling rate of $0.7 \mathrm{~L} / \mathrm{min}$. The $\mathrm{NO}$ analyzer was calibrated after each set of experiments. Calibration was performed using a polytetrafluoroethylene sample-line filter, which was also used during analysis. The flow rate for calibration was higher than the total flow rate required by the analyzer and any other flow demand connected to the manifold. The NO analyzer was allowed to sample zero air until a stable reading was obtained. Span adjust was achieved by selecting the desired NO concentrations. The response of the NO analyzer was plotted against the corresponding NO concentrations. The experimental points were connected using a straight line and determined via linear regression techniques. A minimum $R_{2}$ value of $>0.98$ was achieved for all experiments.

The removal rate (\%) of NO was defined as:

$$
\text { NO removal rate }(\%)=\left(C_{0}-C\right) / C_{0} \times 100 \%
$$

where $C_{0}$ and $C$ represent the NO concentrations of the feed and outlet streams, respectively. The reaction of NO with air could be ignored when performing a control experiment with or without light in the absence of photocatalyst. The photocatalytic degradation of NO is a pseudo-first-order reaction, and its kinetics may be expressed as:

$$
\ln C / C_{0}=-k t
$$

where $k$ is the apparent rate constant of pseudo-first order.

\section{Results and discussion}

The morphologies of the $\mathrm{TiO}_{2}$ thin films before and after coating on the porous ceramic foam filters were examined via SEM. Fig. 3(a) and 3(b) show SEM images of the selected area of the bare porous ceramic foam from different angles. The porous structure of the ceramic foam can be seen in the higher-magnification images (Fig. 3(c) and 3(d)). The original surface of the bare ceramic foam was relatively smooth (Fig. 3(c) and $3(\mathrm{~d})$ ) compared with the ceramic foam coated with $\mathrm{TiO}_{2}$ (Fig. 4(c) and 4(d)). The 3D-interconnected porous networks had a large surface-to-volume ratio, so were potentially good adsorption sites for photocatalytic reaction. Chemical composition analyses using EDXS (Fig. 3(e) and 3(f)) showed that no signal corresponding to titanium ( $4.5 \mathrm{keV})$ was detected on the surface of the uncoated porous ceramic foam.

Figure 4 shows SEM images of the selected areas of the $\mathrm{TiO}_{2}$-coated porous ceramic foam. The cross-sectional view and morphology of the $\mathrm{TiO}_{2}$ thin films coated on the ceramic foam 


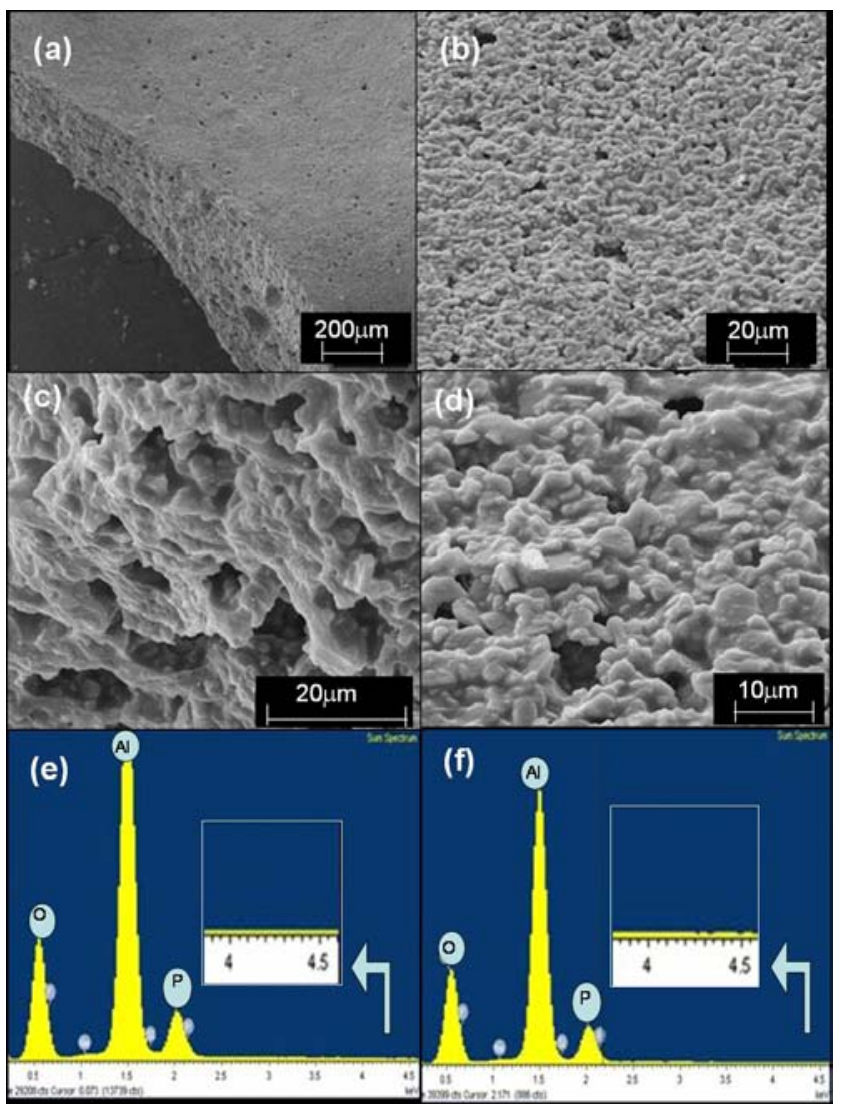

Fig. 3. SEM images (a-d) and EDX microanalysis spectra (e, f) of the uncoated air filters with different magnifications. No signals corresponding to Ti were detected in the EDX microanalysis spectra.

are shown. The rigid surface of the ceramic substrate showed no obvious change after coating with $\mathrm{TiO}_{2}$. Higher-magnification images (Fig. 4(c) and 4(d)) show that the $\mathrm{TiO}_{2}$ was uniformly deposited on the surface of the ceramic foam substrate. The original smooth surface of the ceramic foam (Fig. 3(d)) became rough and squama-like after coating (Fig. 4(d)). To determine the long-term stability of the coating, the $\mathrm{TiO}_{2}$-coated filters were subjected to water washing and recirculation, prior to photocatalytic reactions. The $\mathrm{TiO}_{2}$ thin films were sufficiently robust, with no $\mathrm{TiO}_{2}$ particles detected in the water after washing. The $\mathrm{TiO}_{2}$-coated ceramic surface was

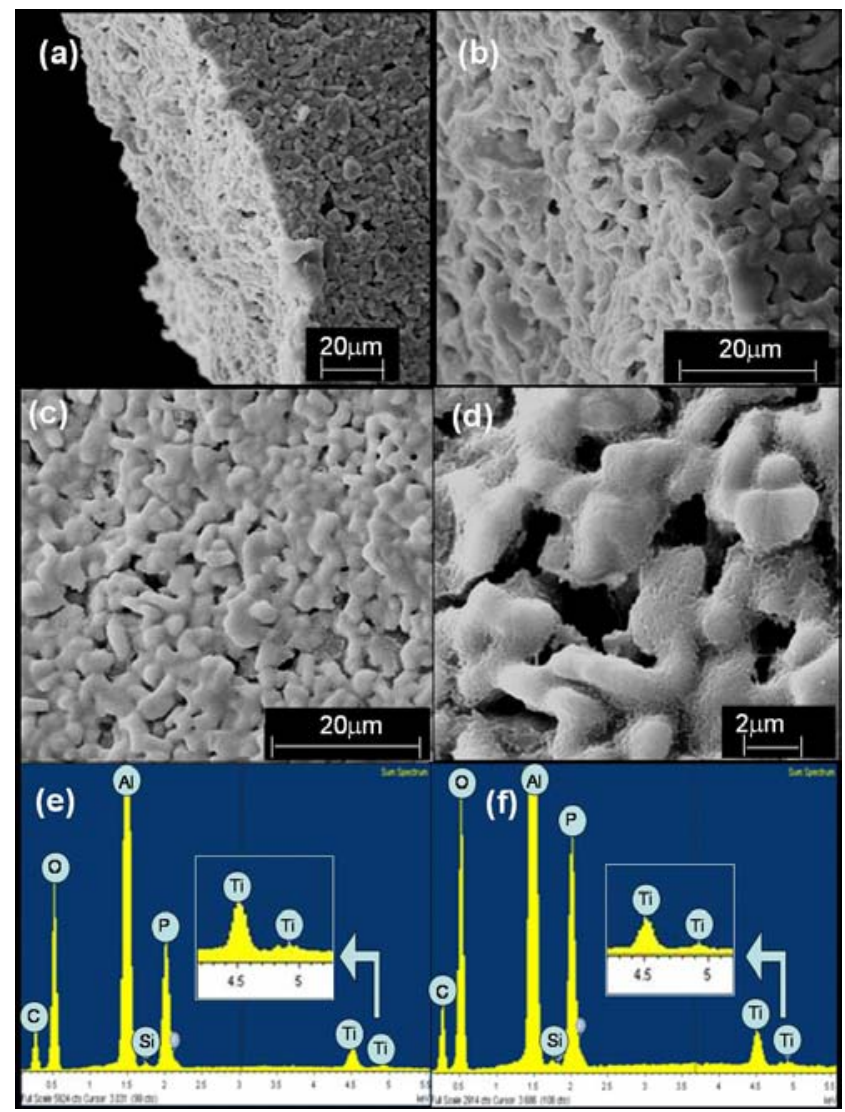

Fig. 4. SEM images (a-d) and EDX microanalysis spectra $(e, f)$ of the $\mathrm{TiO}_{2}$-coated air filters with different magnifications. Ti signals corresponding $\mathrm{TiO}_{2}$ were detected in the EDX microanalysis spectra. The $\mathrm{X}$-ray excitation energy for $\mathrm{Ti}$ is $4.5 \mathrm{keV}$.

rougher than the bare ceramic surface, which caused minimal changes in morphology. The rougher surface provided a larger surface area for photocatalytic reaction.

EDXS was used to determine the chemical composition of the $\mathrm{TiO}_{2}$ thin film on the ceramic foam. Signals corresponding to Ti were detected in the two selected measurement areas (Fig. 4(e) and 4(f)). This indicated that the $\mathrm{TiO}_{2}$ thin films were deposited on the ceramic foam air filters. The spatial distributions of elements in the $\mathrm{TiO}_{2}$ thin film on the ceramic foam were determined by elemental mapping. Fig. 5(a)-5(f) show

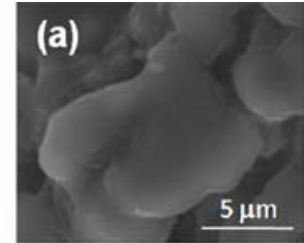

Electron image 1

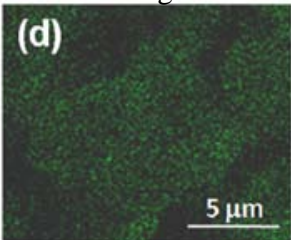

P Ka1

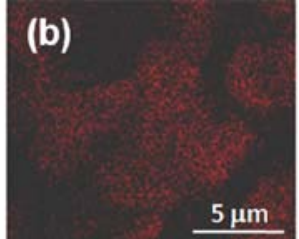

O Ka1

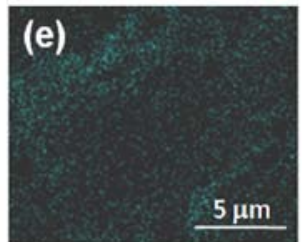

Ti Ka1

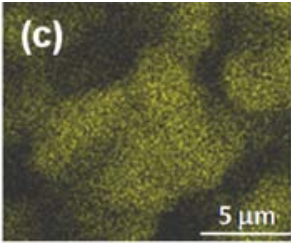

Al Ka1

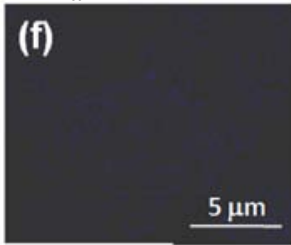

Si Ka1

Fig. 5. SEM image (a) of the $\mathrm{TiO}_{2}$-coated ceramic foam air filter and (b-f) elemental O, $\mathrm{Al}, \mathrm{P}$, $\mathrm{Ti}$, and Si mapping of the image shown in (a), respectively. 


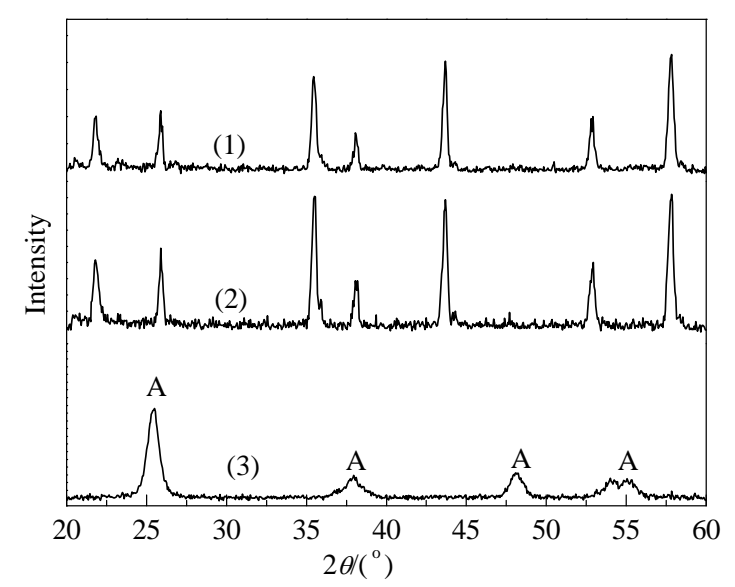

Fig. 6. XRD patterns of the ceramic foam filter substrate (1), $\mathrm{TiO}_{2}$-coated ceramic foam filter $(2), \mathrm{TiO}_{2}$ powders prepared from similar deposition solution for coating (3). " $\mathrm{A}$ " represents the most intense peak of the anatase phase. The angle of incidence was fixed at $0.5^{\circ}$, and $2 \theta$ was scanned within the range of $20^{\circ}$ to $60^{\circ}$.

bright-field images with $\mathrm{O}, \mathrm{Al}, \mathrm{P}, \mathrm{Ti}$, and $\mathrm{Si}$ present in the same region of the sample. The $\mathrm{TiO}_{2}$-coated ceramic foam mainly consisted of homogenously distributed $\mathrm{Ti}, \mathrm{Al}, \mathrm{P}$, and $\mathrm{O}$.

XRD was used to investigate the phase composition of the $\mathrm{TiO}_{2}$ thin film on the ceramic foam. Fig. 6 and Fig. 7 show XRD patterns of the bare and $\mathrm{TiO}_{2}$-coated ceramic foam filters, respectively. The XRD patterns' most intense peak was that of anatase $\mathrm{TiO}_{2}$ at $25.4^{\circ}$, which overlapped with strong peaks of the ceramic substrate. The XRD peak intensities for the $\mathrm{TiO}_{2}$ on the ceramic foam were relatively weak compared with those from the ceramic substrate (Fig. 6). Thus, only peaks of the ceramic substrate were observed in the XRD patterns (Fig. 6). To determine the crystal phase of the deposited $\mathrm{TiO}_{2}, \mathrm{TiO}_{2}$ powders were prepared from a similar deposition solution but without coating on the ceramic foam substrate. Fig. 6(3) shows the XRD pattern of the $\mathrm{TiO}_{2}$ powder sample, which was consistent with anatase. Therefore, the mesoporous $\mathrm{TiO}_{2}$ thin film on the ceramic foam (Fig. 4(d)) consisted of many small anatase $\mathrm{TiO}_{2}$ crystallites.

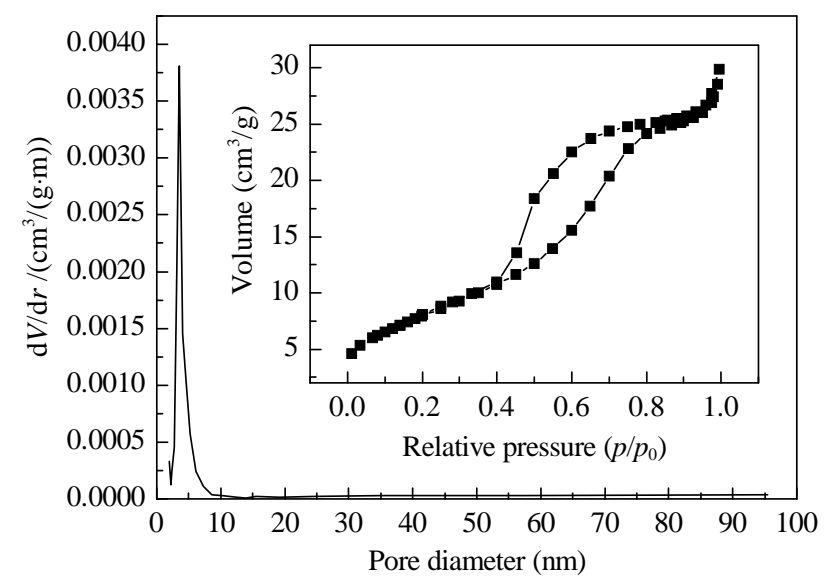

Fig. 7. Pore size distribution curve of $\mathrm{TiO}_{2}$ powders prepared from the $\mathrm{TiO}_{2}$ solutions. Inset: the corresponding nitrogen adsorption-desorption isothermals.

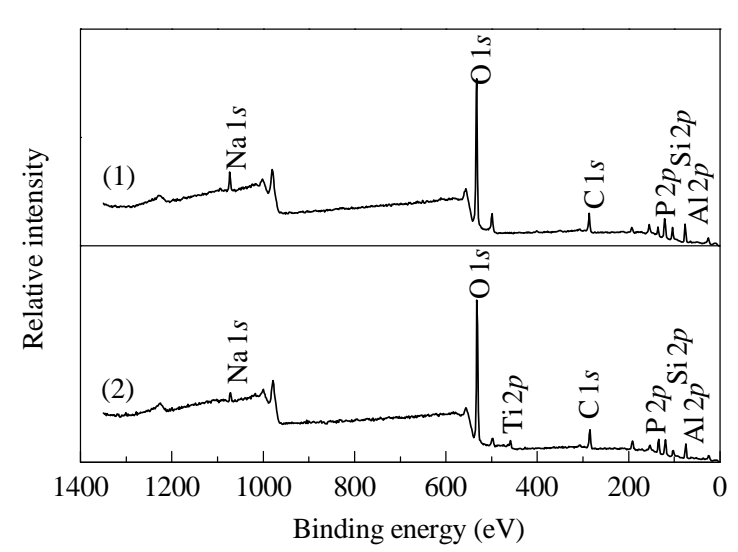

Fig. 8. XPS survey spectra of the uncoated (1) and $\mathrm{TiO}_{2}$-coated ceramic foam air filters (2).

The BET surface areas of the mesoporous $\mathrm{TiO}_{2}$ thin films on the ceramic foam substrates could not be measured directly by nitrogen sorption, because the amount of the thin film was too small. Instead, BET surface areas were measured on powder samples prepared by the same procedure as the thin films. Fig. 7 shows the pore size distribution curves calculated from desorption branches of the nitrogen isotherms, by the BJH method using the Halsey equation. Both samples exhibited narrow pore size distributions. The inset shows the corresponding nitrogen isotherm of the $\mathrm{TiO}_{2}$. The sample exhibited a type-IV isotherm with a sharp decline in the desorption curve, typical of mesoporous solids. Such strong hysteresis is believed to relate to capillary condensation associated with the mesopores. These mesoporous structures allow rapid diffusion of reactants and products, which enhances the rate of photocatalysis.

The chemical composition of the $\mathrm{TiO}_{2}$ thin film on the ceramic foam filter was determined using XPS. Fig. 9 shows the XPS survey spectra of the $\mathrm{TiO}_{2}$ thin film on the ceramic foam filter. The film contained Ti, O, C, Al, P, Si and Na. Peaks for the Ti $2 p$ state were observed at a binding energy $\left(E_{\mathrm{b}}\right)$ of $458.6 \mathrm{eV}$, those for $01 s$ at $E_{\mathrm{b}}=531.9 \mathrm{eV}, \mathrm{Na} 1 s$ at $E_{\mathrm{b}}=1071.8 \mathrm{eV}, \mathrm{P} 2 p$ at $E_{\mathrm{b}}=134.5 \mathrm{eV}, \mathrm{Si} 2 p$ at $E_{\mathrm{b}}=102.6 \mathrm{eV}$, and $\mathrm{Al} 2 p$ at $E_{\mathrm{b}}=74.9 \mathrm{eV}$. The high-resolution XPS spectra (Fig. 9) showed the Ti $2 p_{3 / 2}$ state at $458.7 \mathrm{eV}$ and the Ti $2 p_{1 / 2}$ state at $464.3 .8 \mathrm{eV}$, consistent with the presence of $\mathrm{TiO}_{2}$. Table 1 shows the atomic percentages of the bare and $\mathrm{TiO}_{2}$-coated ceramic foam filters. A significant amount of $\mathrm{Ti}$ was detected after $\mathrm{TiO}_{2}$ coating. The XPS results are consistent with the EDX results, indicating the presence of $\mathrm{Ti}$ in the samples after $\mathrm{TiO}_{2}$ coating.

The photocatalytic performances of the $\mathrm{TiO}_{2}$-coated porous ceramic air filters with different pore densities were evaluated from the degradation of NO under UV irradiation. Fig. 10 shows that the NO concentration sharply decreased when the UV light was switched on for all air filters. A higher pore density (e.g. 30

\section{Table 1}

Atomic concentrations (\%) of the uncoated and $\mathrm{TiO}_{2}$-coated ceramic foam air filters from XPS analysis.

\begin{tabular}{lccccccc}
\hline Sample & $\mathrm{C}$ & $\mathrm{O}$ & $\mathrm{Na}$ & $\mathrm{Al}$ & $\mathrm{Si}$ & $\mathrm{P}$ & $\mathrm{Ti}$ \\
\hline Uncoated air filter & 16.9 & 59.2 & 4.5 & 12.9 & 3.6 & 3.0 & 0.0 \\
$\mathrm{TiO}_{2}$-coated air filter & 18.0 & 58.0 & 1.9 & 11.6 & 2.9 & 6.2 & 1.5 \\
\hline
\end{tabular}




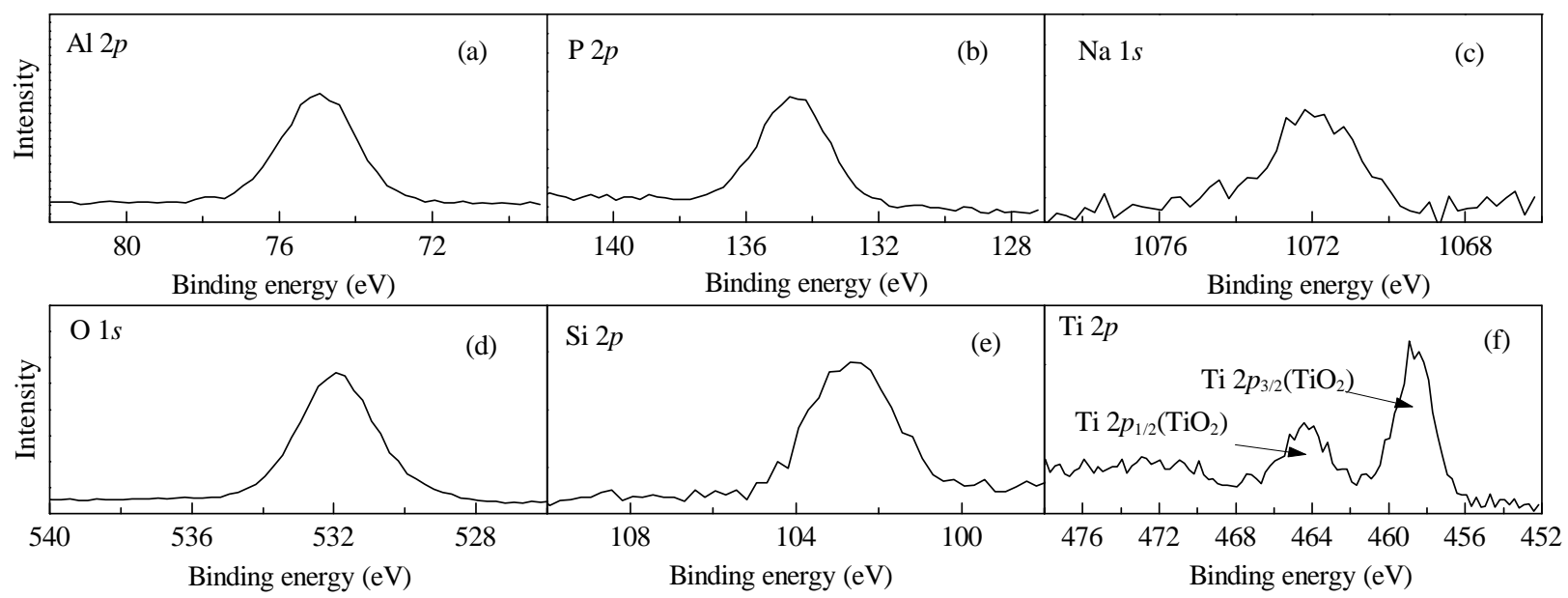

Fig. 9. High-resolution XPS spectra of $\mathrm{Al} 2 p$ (a), $\mathrm{P} 2 p$ (b), $\mathrm{Na} 1 s$ (c), $\mathrm{O} 1 s$ (d), $\mathrm{Si} 2 p$ (e), and Ti $2 p$ (f) regions for the $\mathrm{TiO}_{2}$-coated ceramic foam air filter.

pores per inch (ppi)) resulted in higher photocatalytic efficiency. The $\mathrm{TiO}_{2}$-coated porous ceramic filters with 30 and 20 ppi degraded $79 \%$ and $76 \%$ of NO in a single pass, respectively. The air filter with a lower pore density of 10 ppi degraded $65 \%$ of NO in a single pass. This indicated that an optimum pore density was critical for photocatalytic efficiency. A low pollutant concentration was employed in this study. The effect of the adsorption of pollutants and water vapor is more pronounced at the ppb-level concentration of pollutants than at the current ppm-level concentrations. In this study, the NO concentration was maintained at $<1000 \mathrm{ppb}$. The ceramic foam filters with a high pore density had abundant adsorption sites for water vapor and pollutants, which enhanced the photocatalytic efficiency. More than $95 \%$ of NO was degraded in a single pass for all air filter samples with different pore densities when two $\mathrm{TiO}_{2}$-coated foam ceramic filters were used.

Figure 11 shows the photocatalytic oxidation of NO and the conversion of $\mathrm{NO}_{2}$ from $\mathrm{NO}$ for the $\mathrm{TiO}_{2}$-coated ceramic foam air filter with 30 ppi under UV irradiation. The background concentration inside the test chamber was $16 \mathrm{ppb}$. After the UV

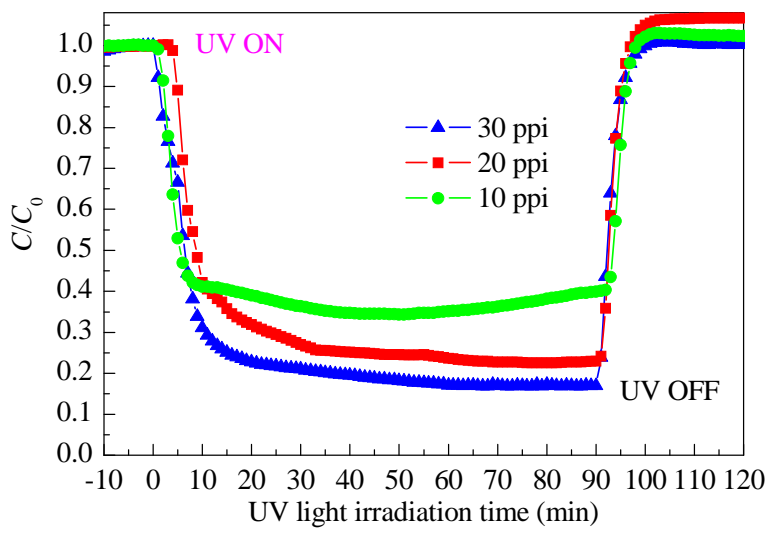

Fig. 10. Photocatalytic degradation of NO for the $\mathrm{TiO}_{2}$-coated ceramic foam air filters with different pore densities (pores per inch (ppi)) under UV light irradiation. Dimension of air filter used $=30 \mathrm{~cm} \mathrm{(L)} \times 30 \mathrm{~cm}$ (W) $\times 1 \mathrm{~cm} \mathrm{(H);} \mathrm{integrated} \mathrm{UV} \mathrm{intensity} \mathrm{within} \mathrm{the} \mathrm{range} \mathrm{of} 310$ to 400 $\mathrm{nm}=540 \pm 10 \mu \mathrm{W} / \mathrm{cm}^{2} ; \mathrm{RH}=65 \% \pm 5 \%$; Temp. $=22 \pm 2^{\circ} \mathrm{C}$; initial NO concentration $=1000 \mathrm{ppb}$. light was switched on, $\mathrm{NO}_{2}$ functioned as the intermediate in the photocatalytic degradation of NO. The amount of generated $\mathrm{NO}_{2}$ increased with reaction time, reaching a constant concentration of $58 \mathrm{ppb}$. $\mathrm{NO}_{2}$ was continuously formed and transformed into $\mathrm{HNO}_{3}$ during irradiation. $\mathrm{NO}_{x}$ ( $\mathrm{NO}$ and $\mathrm{NO}_{2}$ ) are major pollutants in our environment, and are harmful to human health. Evaluating the photocatalytic activity of the $\mathrm{TiO}_{2}$-coated filters based on the NO removal rate is therefore insufficient. More attention should be given to the conversion of $\mathrm{NO}_{2}$ to $\mathrm{HNO}_{3}$ because the latter can be easily removed. Previous studies [53-57] have shown that $\mathrm{NO}_{2}$ is the intermediate generated in the photocatalytic degradation of NO, which is supported by the following reactions:

$$
\begin{aligned}
& \mathrm{NO}+\mathrm{HO}_{2} \bullet \rightarrow \mathrm{NO}_{2}+\mathrm{OH}^{\bullet} \\
& \mathrm{NO}_{2}+\mathrm{OH} \cdot \rightarrow \mathrm{HNO}_{3}
\end{aligned}
$$

$\mathrm{NO}_{2}$ functions as the intermediate during the photocatalytic oxidation of NO, and can further react with $\mathrm{OH} \cdot$ to form $\mathrm{HNO}_{3}$ $[33,34]$. The oxidation of NO is reportedly the major process in

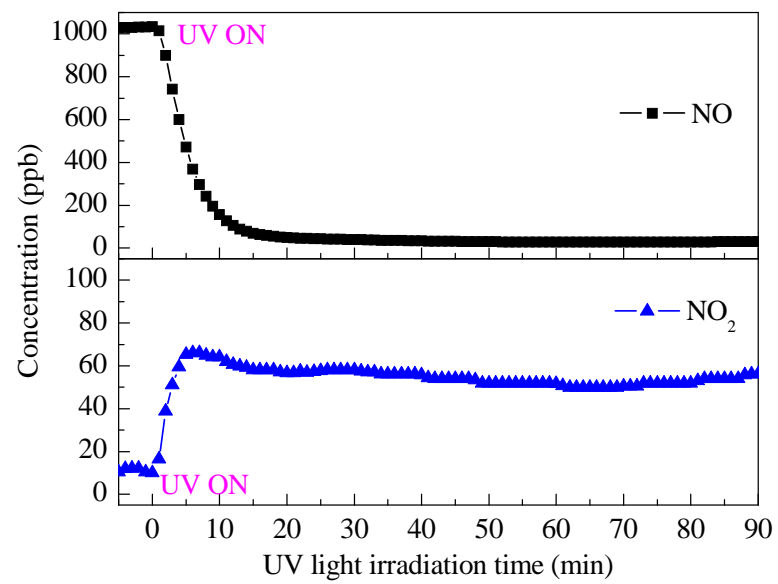

Fig. 11. Photocatalytic oxidation of $\mathrm{NO}$ and the conversion of $\mathrm{NO}_{2}$ from NO for the $\mathrm{TiO}_{2}$-coated ceramic foam air filter with 30 ppi under UV light irradiation. Dimension of the air filter used $=60 \mathrm{~cm} \mathrm{(L)} \times 30 \mathrm{~cm}(\mathrm{~W}$ $\times 1 \mathrm{~cm}(\mathrm{H})$; integrated UV intensity within the range of 310 to $400 \mathrm{~nm}=$ $540 \pm 10 \mu \mathrm{W} / \mathrm{cm}^{2} ; \mathrm{RH}=65 \% \pm 5 \%$; Temp. $=22 \pm 2{ }^{\circ} \mathrm{C}$; initial NO concentration $=1000 \mathrm{ppb}$. 
the photocatalytic removal of NO. NO is directly oxidized to $\mathrm{NO}_{3}{ }^{-}$by some oxidative species generated under solar excitation, such as photogenerated holes and $\cdot \mathrm{OH}$ and $\cdot \mathrm{O}_{2}-$ radicals [58-62]:

$$
\begin{aligned}
& \text { Photocatalysts }+\mathrm{hv} \rightarrow \mathrm{h}^{+}+\mathrm{e}^{-} \\
& \mathrm{h}^{+}+\mathrm{H}_{2} \mathrm{O} \rightarrow \cdot \mathrm{OH}+\mathrm{H}^{+} \\
& \mathrm{e}^{-}+\mathrm{O}_{2} \rightarrow \cdot \mathrm{O}_{2^{-}} \\
& \mathrm{h}^{+}+\mathrm{NO}+\mathrm{H}_{2} \mathrm{O} \rightarrow \mathrm{NO}_{3}-+2 \mathrm{H}^{+} \\
& 2 \cdot \mathrm{OH}+\mathrm{NO} \rightarrow \mathrm{NO}_{3}+\mathrm{H}_{2} \mathrm{O} \\
& \cdot \mathrm{O}_{2^{-}}+\mathrm{NO} \rightarrow \mathrm{NO}_{3}-
\end{aligned}
$$

Thus, $\mathrm{NO}_{2}$ generated from the photodegradation of NO was adsorbed on the ceramic foam air filters because of their large adsorption capacities. Adsorbed $\mathrm{NO}_{2}$ was photodegraded to $\mathrm{HNO}_{3}$, which reduced the amount of $\mathrm{NO}_{2}$ exiting the system. This result further confirmed that the $\mathrm{TiO}_{2}$ thin film coated on the ceramic foam filters efficiently removed $\mathrm{NO}$ and $\mathrm{NO}_{2}$.

Repeatability and long-life photocatalytic activity are important for photocatalysis, and in minimizing the frequency of air filter replacements. Fig. 12 shows the effect of the reaction cycle on the photocatalytic activity of the $\mathrm{TiO}_{2}$-coated ceramic filters, for the photocatalytic degradation of NO with an initial concentration of $400 \mathrm{ppb}$. After sorption equilibrium, the UV light was turned on for more than $1 \mathrm{~h}$, and then turned off for more than $1 \mathrm{~h}$, to recover sorption equilibrium. This process was repeated three times to evaluate the effect of increasing the reaction cycle on the photocatalytic activity of the $\mathrm{TiO}_{2}$-coated porous ceramic filters. The NO concentration rapidly decreased to a very low level when the UV lamp was switched on. The NO concentration gradually decreased with prolonged UV irradiation time. The air filter samples with different pore densities degraded $92.5 \%-97.5 \%$ of NO. The photocatalytic oxidation of NO was similar between reaction cycles, with previous cycles having no evident effect on the photocatalysis of the $\mathrm{TiO}_{2}$-coated filters.

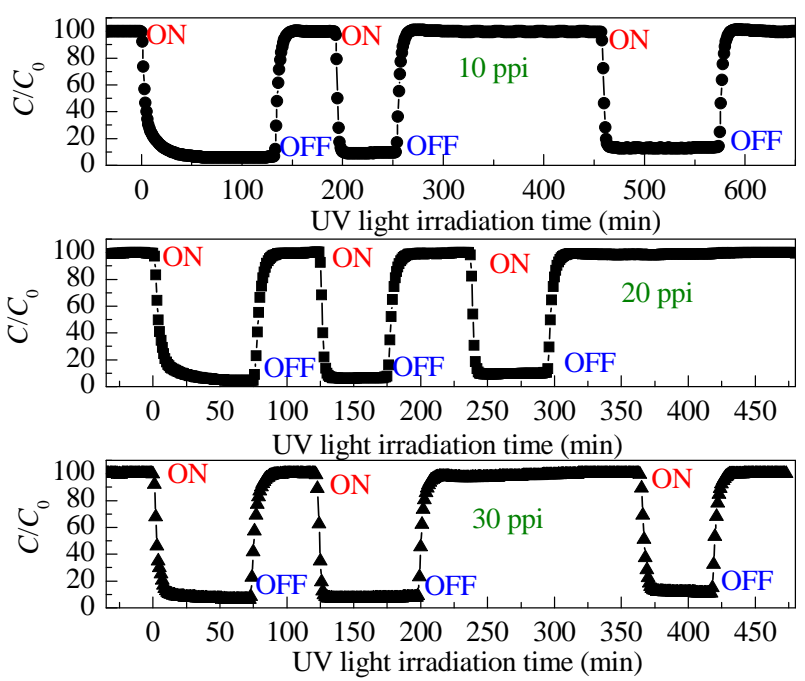

Fig. 12. Photocatalytic degradation of NO in different repeated cycles for the $\mathrm{TiO}_{2}$-coated ceramic foam air filters with different pore densities (pores per inch (ppi)) under UV light irradiation. Dimension of the air filter used $=30 \mathrm{~cm} \mathrm{(L)} \times 30 \mathrm{~cm}(\mathrm{~W}) \times 1 \mathrm{~cm} \mathrm{(H)}$; integrated UV intensity within the range of 310 to $400 \mathrm{~nm}=540 \pm 10 \mu \mathrm{W} / \mathrm{cm}^{2} ; \mathrm{RH}=65 \% \pm 5 \%$; Temp. $=22 \pm 2{ }^{\circ} \mathrm{C}$; initial NO concentration $=400 \mathrm{ppb}$.
NO was photocatalytically degraded to $\mathrm{NO}_{2}$, and then further oxidized to $\mathrm{HNO}_{3}$ upon UV irradiation. Fig. 11 shows that the concentration of the $\mathrm{NO}_{2}$ intermediate in the outlet gas was maintained at a low level. Thus, most of the $\mathrm{NO}$ and $\mathrm{NO}_{2}$ intermediates were photocatalytically oxidized to $\mathrm{HNO}_{3}$, which could potentially have progressively adsorbed at $\mathrm{TiO}_{2}$ active sites. This competitive adsorption between $\mathrm{HNO}_{3}$ and $\mathrm{NO}$ could have decreased the rate of photocatalytic oxidation of NO to $\mathrm{NO}_{2}$, and thus decreased the photocatalytic activity of the $\mathrm{TiO}_{2}$ thin film. However, no such decrease in photocatalytic activity was observed based on the above reaction cycle testing. $\mathrm{HNO}_{3}$ adsorbed at active sites transferred to non-active sites of the $\mathrm{TiO}_{2}$ coating, or to the surface of the ceramic foam substrate, so active sites on the $\mathrm{TiO}_{2}$ surface were recovered. Thus, the $\mathrm{NO}_{2}$ intermediate did not accumulate at $\mathrm{TiO}_{2}$ active sites, and did not deactivate the photocatalyst.

To further evaluate the effect of the 3D porous foamed structure of the filter on the photocatalytic efficiency of $\mathrm{TiO}_{2}$ coating, the $\mathrm{TiO}_{2}$ thin film was prepared on flat ceramic tiles using similar deposition conditions. Table 2 compares the photocatalytic activities for the degradation of NO between the $\mathrm{TiO}_{2}$ thin film deposited on the porous ceramic foam filters, and that coated on the flat ceramic tiles. The $\mathrm{TiO}_{2}$ thin film coated on the 3D porous ceramic foam exhibited a higher photocatalytic activity. This confirmed that the photocatalytic oxidation of NO diffused into the ceramic foam, because of its large surface area. The photocatalytic oxidation only occurred on the surface of the $\mathrm{TiO}_{2}$ thin film on the flat ceramic tiles. No further space was available for NO diffusion, which decreased the photocatalytic efficiency. Another factor affecting photocatalytic performance is the nature of the UV light. Light naturally travels from its source (UV lamp) with some degree of divergence, ensuring that the entire top surface of the air filters was irradiated. The UV light intensity was lower within the 3D porous

Table 2

Photocatalytic degradation of $\mathrm{NO}$ for the $\mathrm{TiO}_{2}$-coated ceramic foam air filters with different pore densities.

\begin{tabular}{lcc}
\hline Sample & $\begin{array}{c}\text { Initial NO } \\
\text { conc. }(\mathrm{ppb})\end{array}$ & $\begin{array}{c}\text { Degradation of NO } \\
\text { in single pass (\%) }\end{array}$ \\
\hline $\mathrm{TiO}_{2}$-coated ceramic filter-10 ppi & 400 & 92.5 \\
$\mathrm{TiO}_{2}$-coated ceramic filter-20 ppi & 400 & 97.5 \\
$\mathrm{TiO}_{2}$-coated ceramic filter-30ppi & 400 & 95 \\
Pure ceramic filter-10 ppi & 1000 & 0 \\
Pure ceramic filter-20 ppi & 1000 & 0 \\
Pure ceramic filter-30 ppi & 1000 & 0 \\
$\mathrm{TiO}_{2}$-coated ceramic filter-10 ppi & 1000 & 65 \\
$\mathrm{TiO}_{2}$-coated ceramic filter-20 ppi & 1000 & 76 \\
$\mathrm{TiO}_{2}$-coated ceramic filter-30 ppi & 1000 & 79 \\
$2 \times \mathrm{TiO}_{2}$-coated ceramic filter-10 ppi & 1000 & 97 \\
$2 \times \mathrm{TiO}_{2}$-coated ceramic filter-20 ppi & 1000 & 98 \\
$2 \times \mathrm{TiO}_{2}$-coated ceramic filter-30 ppi & 1000 & 95 \\
$\mathrm{TiO}_{2}$-coated ceramic tile & 400 & 72.5 \\
$\mathrm{TiO}_{2}$-coated ceramic tile & 1000 & 43 \\
\hline
\end{tabular}

The initial NO concentrations $=400$ or $1000 \mathrm{ppb}$. Dimensions of the air filters and tiles used under UV light irradiation $=30 \mathrm{~cm}(\mathrm{~L}) \times 30 \mathrm{~cm}(\mathrm{~W})$ $\times 1 \mathrm{~cm}(\mathrm{H})$ or $60 \mathrm{~cm}(\mathrm{~L}) \times 30 \mathrm{~cm}(\mathrm{~W}) \times 1 \mathrm{~cm}(\mathrm{H})$. Integrated UV intensity within the range of 310 to $400 \mathrm{~nm}=540 \pm 10 \mu \mathrm{W} / \mathrm{cm}^{2} ; \mathrm{RH}=65 \% \pm 5 \%$; Temp. $=22 \pm 2{ }^{\circ} \mathrm{C}$. 
ceramic foam filters, depending on the penetration depth and scattering. More UV light may have penetrated into lower pore density filters. The photocatalytic activity of the $\mathrm{TiO}_{2}$-coated 20 ppi porous ceramic filter was similar to or even higher than that of the 30 ppi filter. Further studies are needed to elucidate this phenomenon.

\section{Conclusions}

Mesoporous $\mathrm{TiO}_{2}$ thin films were formed on 3D porous ceramic air filters with a high surface area, via the reverse micellar method. The photocatalytic degradation of NO was evaluated on these mesoporous $\mathrm{TiO}_{2}$-coated porous ceramic air filters. The efficient photocatalytic degradation of NO resulted from the large effective surface area and high photocatalytic activity of the mesoporous $\mathrm{TiO}_{2}$ thin film coating. More than $92.5 \%$ of NO at 400 ppb was degraded in a single pass for the $\mathrm{TiO}_{2}$-coated ceramic foam filters with different pore densities. The 3D porous structure of the ceramic filters enhanced flow turbulence and mixing, providing sufficient contact between the reactant gas and $\mathrm{TiO}_{2}$ surface. A higher pore density of the ceramic foam filter resulted in a higher photocatalytic rate. The $\mathrm{TiO}_{2}$-coated $3 \mathrm{D}$ porous ceramic filters exhibited a higher photocatalytic degradation rate of $\mathrm{NO}$ than that of $\mathrm{TiO}_{2}$-coated flat ceramic tiles. The 3D porous ceramic filters maintained a consistently high degradation rate between reaction cycles, indicating that the photocatalyst did not become deactivated.

\section{Acknowledgments}

This research is financially supported by the Research Grant of the Early Career Scheme (ECS 809813) from the Research Grant Council, Hong Kong SAR Government, the Dean's Research Fund-Early Career Researchers (04022), the Research Equipment Grant (REG-2), and the Internal Research Grant (R3429) from the Hong Kong Institute of Education. This study is also supported by the grants from the Research Grants Council of the Hong Kong Special Administrative Region, China (PolyU 5204/07E) and the Hong Kong Polytechnic University (GYX75).

\section{References}

[1] Jones A P. Atoms Environ, 1999, 33: 4535

[2] Ao C H, Lee S C. Appl Catal B, 2003, 44: 191

[3] Ao C H, Lee S C, Mak C L, Chan L Y. Appl Catal B, 2003, 42: 119

[4] Robinson J, Nelson W C. National Human Activity Pattern Survey Data Base. United States Environmental Protection Agency (USEPA), Research Triangle Park, NC, 1995.

[5] United States Environmental Protection Agency. EPA Report: Characterizing Air Emissions from Indoor Sources. Washingtion DC, 1995. EPA/600/F-95/005

[6] Baek S O, Kim Y S, Perry R. Atoms Environ, 1997, 31: 529

[7] Khan F I, Ghoshal A K. J Loss Prev Process Ind, 2000, 13: 527

[8] Schleibinger H, Ruden H. Atmos Environ, 1999, 33: 4571

[9] Fujishima A, Honda K. Nature, 1972, 238: 37

[10] Tada H, Yamamoto M, Ito S. Langmuir, 1999, 15: 3699

[11] Yu J G, Zhou M H, Cheng B, Yu H G, Zhao X J. J Mol Catal A, 2005, 227: 75

[12] Qi L F, Ho W K, Wang J L, Zhang P Y, Yu J G. Catal Sci Technol, 2015, 5: 2366

[13] Li F B, Li X Z. Appl Cata A, 2002, 228: 15

[14] Peral J, Ollis D F. J Catal, 1992, 136: 554

[15] Yu J G, Yu J C, Leung M K P, Ho W K, Cheng B, Zhao X J, Zhao J C. J Catal, 2003, 217: 69

[16] Yu J C, Ho W K, Lin J, Yip H, Wong P K. Environ Sci Technol, 2003, 37: 2296

[17] Fan X X, Wang Y, Chen X Y, Gao L, Luo W J, Yuan Y P, Li Z S, Yu T, Zhu J H, Zou Z G. Chem Mater, 2010, 22: 1276

[18] Zheng L P, Yan G Y, Huang Y Y, Wang X X, Long J L, Li L, Xu T Y. Int J Hydrogen Energy, 2014, 39: 13401

[19] Ouyang S X, Li P, Xu H, Tong H, Liu L Q, Ye J H. ACS Appl Mater Interfaces, 2014, 6: 22726

[20] Noguchu T, Fujishima A. Sawunyama P, Hashimoto K. Environ Sci Technol, 1998, 32: 3831

[21] Blount M C, Kim D H, Falconer J L. Environ Sci Technol, 2001, 35: 2988

[22] Negishi N, Takeuchi K, Ibusuki T.J Mater Sci Lett, 1999, 18: 515

[23] Negishi N, Takeuchi K. Mater Lett, 1999, 38: 150

[24] Tada H, Tanaka M. Langmuir, 1997, 13: 360

[25] Blimes S A, Mandelbaum P, Alvarez F, Victoria N M. J Phys Chem B, 2000, 104: 9851

[26] Yu J G, Yu H G, Cheng B, Zhao X J, Yu J C, Ho W K. J Phys Chem B, 2003, 107: 13871

\section{Graphical Abstract}

Chin. J. Catal., 2015, 36: 2109-2118 doi: 10.1016/S1872-2067(15)61003-8

Efficient photocatalytic degradation of NO by ceramic foam air filters coated with mesoporous $\mathrm{TiO}_{2}$ thin films

Wingkei Ho*

The Hong Kong Institute of Education;

The Hong Kong Polytechnic University

The mesoporous photocatalytic coating on the 3D porous structure of the ceramic filters enhances flow turbulence and mixing and thus leads to the enhancement in photocatalytic NO degradation.

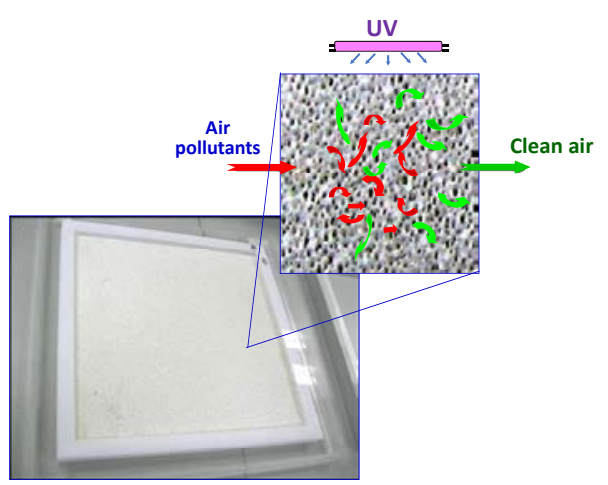


[27] Yu J G, Zhao X J, Zhao Q N. Thin Solid Films, 2000, 379: 7

[28] Balasubramanian G, Dionysiou D D, Suidan M T, Subramanian V, Baudin I, Laine J M. J Mater Sci, 2003, 38: 823

[29] Nagayama H, Honda H, Kawahara H. J Electrochem Soc, 1988, 135 : 2013

[30] Pizem H, Sukenik C N, Sampathkumaran U, Mcllwain A K, De Guire M R. Chem Mater, 2002, 14: 2476

[31] Masuda Y, Ieda S, Koumoto K. Langmuir, 2003, 19: 4415

[32] Deki S, Aoi Y, Hiroi O, Kajinami A. Chem Lett, 1996, (6): 433

[33] Pestryakov A N, Lunin V V, Devochkin A N, Petrov L A, Bogdanchikova N E, Petranovskii V P. Appl Catal A, 2002, 227: 125

[34] Liu H, Cheng S A, Zhang J Q, Cao C N, Zhang S K. Chemosphere, 1999, 38: 283

[35] Leng W H, Liu H, Cheng S A, Zhang J Q, Cao C N. J Photochem Photobiol A, 2000, 131: 125

[36] Richardson J T, Garrait M, Hung J K. Appl Catal A, 2003, 255: 69

[37] Peng Y, Richardson J T. Appl Catal A, 2004, 266: 235

[38] Buciuman F C, Kraushaar-Czarnetzki B. Catal Today, 2001, 69: 337

[39] Hwang K S, Zhu H Y, Lu G Q. Catal Today, 2001, 68: 183

[40] Ding Z, Hu X J, Yue P L, Lu G Q, Greenfield P F. Catal Today, 2001, 68: 173

[41] Infantes-Molina A, Merida-Robles J, Braos-Garcia $\mathrm{P}$, Rodriguez-Castellon E, Finocchio E, Busca G, Maireles-Torres P, Jimenez-Lopez A.J Catal, 2004, 225: 479

[42] Atienzar P, Corma A, Garcia H, Scaiano J C. Chem Mater, 2004, 16: 982

[43] Lam F L Y, Hu X J. Chem Eng Sci, 2003, 58: 687

[44] Yu J C, Wang X C, Wu L, Ho W K, Zhang L Z, Zhou G T. Adv Funct Mater, 2004, 14: 1178
[45] Zhao D Y, Feng J L, Huo Q S, Melosh N, Frederickson G H, Chmelka B F, Stucky G D. Science, 1998, 249: 458

[46] Stathatos E, Lianos P, DelMonte F, Levy D, Tsiourvas D. Langmuir, 1997, 13: 4295

[47] Stathatos E, Lianos P, Falaras P, Siokou A. Langmuir, 2000, 16: 2398

[48] Ho W K, Yu J C, Lee S C. Appl Catal B, 2007, 73: 135

[49] Yu J C, Ho W K, Yu J G, Hark S K, Iu K S. Langmuir, 2003, 19: 3889

[50] Weschler C J, Shields H C, Naik D V. Environ Sci Technol, 1994, 28: 2120

[51] Komazaki Y, Shimizu H, Tanaka S. Atmos Environ, 1999, 33: 4363

[52] Matsuda S, Hatano H, Tsutsumi A. Chem Eng J, 2001, 82: 183

[53] Hashimoto K, Wasada K, Osaki M, Shono E, Adachi K, Toukai N, Kominami H, Kera Y. Appl Catal B, 2001, 30: 429

[54] Dalton J S, Janes P A, Jones N G, Nicholson J A, Hallam K R, Allen G C. Environ Pollut, 2002, 120: 415

[55] Nakamura I, Negishi N, Kutsuna S, Ihara T, Sugihara S, Takeuchi K. J Mol Catal A, 2000, 16: 205

[56] Dong G H, Ho W K, Zhang L Z. Appl Catal B, 2015, 168: 490

[57] Ho W K, Zhang Z Z, Lin W, Huang S P, Zhang X W, Wang X X, Huang Y. ACS Appl Mater Interf, 2015, 7: 5497

[58] Ai Z H, Lee S C. Appl Surf Sci, 2013, 280: 354

[59] Ge S X, Zhang L Z. Environ Sci Technol , 2011, 45: 3027

[60] Dong F, Wang Z Y, Li Y H, Ho W K, Lee S C. Environ Sci Technol, 2014, 48: 10345

[61] Sugrañez R, Balbuena J, Cruz-Yusta M, Martín F, Morales J, Sánchez L. Appl Catal B, 2015, 165: 529

[62] Ding X, Song X, Li P N, Ai Z H, Zhang L Z.J Hazard Mater, 2011, 190: 604

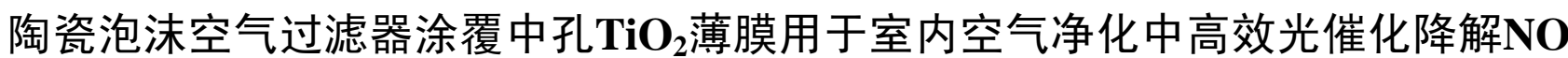

\author{
Wingkei Ho ${ }^{\text {a,b,* }}$ \\ a香港教育学院科学与环境学系和环境可持续教育中心, 香港大埔 \\ b香港理工大学环境技术和管理研究中心土木与环境工程系, 香港
}

摘要: 由于人们 $80 \%$ 的时间呆在室内, 室内空气的质量直接影响人类健康, 因此近年来室内空气质量越来越受到人们的关注. 室 内污染物包括CO氮氧化物 $\left(\mathrm{NO}_{x}\right)$ 和挥发性有机化合物(VOCs), 它们给人体健康带来众多负面影响. 更为重要的是, 考虑到节能, 现代建筑的空气密闭性大都较高, 但这种减少吸入新鲜空气的设计直接导致室内各种污染物的累积. 有些家用电器, 如燃气灶和 热水器, 在使用的时候会涉及到煤、油和天然气的燃烧, 特别是通风较差的情况下会成为室内主要的污染源. 常规的治理技术, 包 括吸附和过滤, 其成本相对较高, 也不适用于低浓度污染物的治理. 尤其是更换不及时的过滤器在排风系统中可能会成为VOCs 的一个来源. 因此, 很有必要开发一种新型的技术以降低室内污染物的浓度和保持一个清洁的室内空气环境, 从而保障人们的身 体健康.

光催化是去除室内空气污染物的有效方法. 例如, $\mathrm{TiO}_{2}$ 、钛酸铋和钛酸锶等具有强氧化能力和稳定的光催化活性, 因而是高效 的光催化剂. 一般而言, 通常报道的 $\mathrm{TiO}_{2}$ 光催化剂是高度分散的、或悬浮于液体介质中的细小颗粒或粉末. 然而, 粉末状的 $\mathrm{TiO}_{2}$ 光催化剂不适宜于室内空气净化, 因为它变得可吸入而对人体健康造成不利的影响. 因此, 人们尝试将 $\mathrm{TiO}_{2}$ 颗粒作为薄膜固定在 不同的刚性载体上, 如玻璃、不锈钢和铝合金板.

对基体进行涂覆可显著影响光催化时反应物的表面吸附行为. 一般而言, 光催化薄膜通常涂覆在平面上, 如蜂窝空气过滤器. 三维(3D)多孔的陶瓷泡沫对气体通过具有非常好的流体性质, 因此本文以它作为涂覆的基体. 这种陶瓷泡沫具有3D多孔结构, 多 种孔密度、比表面积和化学性质. 3D多孔陶瓷泡沫空气过滤器的床层空隙率较高, 因此使用时压降较低, 且不像蜂窝空气过滤器, 它具有复杂多变的孔结构, 可增强流体的扰动和混合. 另外, 3D多孔陶瓷泡沫空气过滤器的开发多孔和网状的结构使得在催化体 系具有非常好的气体动力学性质, 催化剂表面和气体反应物有充分的接触. 多孔材料在液相或气相催化反应中具有独特的优势, 因此, 陶瓷泡沫、多孔的氧化铝、多孔硅胶. 分子篮和活性炭经常被用作催化剂载体.

在固体基体上 $\mathrm{TiO}_{2}$ 膜的形成可能使得 $\mathrm{TiO}_{2}$ 光催化剂的有效比表面积降低, 从而导致其光催化活性下降. 然而, 由于具有中孔 结构的 $\mathrm{TiO}_{2}$ 薄膜的比表面积大, 其用于催化反应的活性位也更多, 因此使用时仍然具有较高的活性. 前期研究表明, 涂覆在平面 玻璃、不锈钢和氧化铝基体上的中孔 $\mathrm{TiO}_{2}$ 薄膜用于环境净化时表现出增强的光催化效率. 另外, 室内环境中 $\mathrm{NO}$ 和 $\mathrm{NO}_{2}$ 的浓度一般 
分别为几百个 $\mathrm{ppb}$ 之内和 $100 \mathrm{ppb}$ 以下. 可见, $\mathrm{NO}$ 是主要的室内空气污染物, 对人体健康危害较大. 基于此, 本文首次采用反胶束 法将中孔锐铁矿 $\mathrm{TiO}_{2}$ 薄膜均匀一地涂覆在 $3 \mathrm{D}$ 多孔高比表面积的泡沫过滤器上, 采用X射线衍射、扫描电镜、X射线光电子能谱、 $\mathrm{N}_{2}$ 吸附-脱附、紫外-可见光光谱和原子力显微镜对所制样品进行了表征, 并将样品用于紫外光下催化降解NO, 以揭示所制的中孔 $\mathrm{TiO}_{2}$ 涂层具有高的比表面积和高的光催化活性, 从而克服使用 $\mathrm{TiO}_{2}$ 粉末所带来的不足.

结果表明, 由于中孔 $\mathrm{TiO}_{2}$ 薄膜涂层具有较大的有效比表面积, 其表面存在很多吸附活性位, 用于吸附在反应过程中形成的水 蒸汽、气相反应物和产物, 因而具有更高的光催化活性, 因此在陶瓷泡沫空气净化系统中可以高效地光催化NO降解: 在所考察的 不同孔密度的陶瓷泡沫过滤器涂覆的 $\mathrm{TiO}_{2}$ 上 $400 \mathrm{ppb}$ 的 $\mathrm{NO}$ 单程转化率均在 $92.5 \%$ 以, 高于涂覆在平面陶瓷砖上的 $\mathrm{TiO}_{2}$. 该陶瓷 过滤器的3D多孔特性可增强流体的扰动和混合, 使得气相反应物与光催化剂表面有着充分的接触; 其大的孔密度也导致高的光 催化速率. 另外, 本文所制样品在所有反应过程中均保持较高且稳定的NO降解速率, 这表明其在NO降解反应中没有失活.

关键词: 二氧化钛; 光催化;陶瓷; 一氧化氮; 涂覆

收稿日期: 2015-08-31. 接受日期: 2015-10-29. 出版日期: 2015-12-20.

*通讯联系人. 电话: +852-29488255; 电子信箱: keithho@iededuhk

基金来源：香港特别行政区政府研究资助局杰出青年学者计划(ECS 809813); 香港教育学院院长研究基金-青年学者计划 (04022); 香港教育学院研究设备补助金(REG-2); 香港教育学院内部研究资助(R3429); 香港特别行政区政府研究资助局优配研 究金(PolyU 5204/07E); 香港理工大学内部研究资助(GYX75).

本文的英文电子版由Elsevier出版社在ScienceDirect上出版(http://www.sciencedirect.com/science/journal/18722067). 